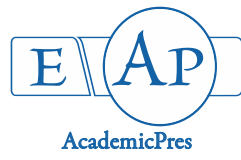

\title{
Acute and Sub-acute Toxicity of Ganoderma applanatum (Pres.) Pat. Extract Mediated Silver Nanoparticles on Rat
}

\author{
Sukumar DANDAPAT ${ }^{1 *}$, Manoj KUMAR², Rakesh RANJAN ${ }^{1}$, \\ Manoranjan P. SINHA ${ }^{1}$ \\ ${ }^{1}$ Ranchi University, Department of Zoology, Ranchi, 834008, Jharkhand, \\ India; rakeshranjanlal08@gmail.com;dr.mp.sinha@gmail.com;dr.sukumar2018@gmail.com ("correspondingauthor) \\ ${ }^{2}$ St. Xavier's College, Department of Zoology, Ranchi, 834001, Jharkhand, India;dr17mk@gmail.com
}

\begin{abstract}
Ganoderm applanatum is a polypore macrofungus and traditionally used as medicine rather than fodder. Silver nanoparticles mediated by $G$. applanatum extract were synthesized, characterized and toxicity impacts were investigated for their pharmacological and medicinal uses. The synthesized silver nanoparticles were of average $58.78 \mathrm{~nm}$ in diameter with $13.8 \mathrm{mV}$ zetpotential, analysed by dynamic light scattering method. Fourier transform infrared spectroscopy analysis of synthesized nanoparticles confirmed the capping and stabilizing with mycochemicals, that showed transmittance at $3606 \mathrm{~cm}^{-1}$ corresponds to $\mathrm{O}-\mathrm{H}$ stretch for phenol, $2430 \mathrm{~cm}^{-1}$ corresponds to $\mathrm{N}-\mathrm{H}$ stretch for primary and secondary amines. $2000 \mathrm{mg}$ $\mathrm{kg}^{-1}, 200 \mathrm{mg} \mathrm{kg}^{-1}$ and $400 \mathrm{mg} \mathrm{kg}^{-1}$ doses of silver nanoparticles showed insignificant $(\mathrm{p}<0.05)$ increase in body weight and organ weight. Insignificant increase in RBC indices were observed and significant $(\mathrm{p}<0.05)$ increase in WBC count $\left(7.28 \pm 0.41 \times 10^{3}\right.$ $\mu \mathrm{L}^{-1}$ and $\left.8.41 \pm 0.35 \times 10^{3} \mu \mathrm{L}^{-1}\right)$ at $200 \mathrm{mg} \mathrm{kg}^{-1}$ and $400 \mathrm{mg} \mathrm{kg}^{-1}$ doses of silver nanoparticles were observed. Thus, $G$. applanatum extract mediated silver nanoparticles can be used pharmacologically and medicinally due to their nontoxic effect.
\end{abstract}

Keywords: fungi; haematology; medicine; nanoparticles; toxicity

Abbreviations: BAS: basophil; BW: body weight; DLS: dynamic light scattering; EOS: eosinophil; FTIR: Fourier - transform infrared spectroscopy; Hb-haemoglobin; HD: high dose; LD: low dose; LYM: lymphocyte; MCHC: mean corpuscles haemoglobin concentration; MCV: mean corpuscles volume; MON: monocyte; NEU: neutrophil; OW: organ weight; PCV: packed cell volume (haematocrit); Pt: platelet; RBC: red blood coruscels; SEM: scanning electron microscopy; SNPs: silver nanoparticles; UV-Vis: ultraviolet visible; WBC: white blood corpuscles; XRD: $\mathrm{x}$-ray diffraction

\section{Introduction}

Human health is threatened by several diseases and disorders which are difficult to treat with systemically and delivered drugs because the absorption and therefore bioavailability of drugs use in conventional pharmacotherapy depends on many factors, such as solubility, $\mathrm{pKa}$, molecular weight, number of bonds per hydrogen atom of the molecule, and chemical stability etc. and all of these can hinder the activity and therapeutic response of drugs (Vilar et al., 2012). Nanotechnology includes the materials in nanoscale ranges $1 \mathrm{~nm}$ to $100 \mathrm{~nm}$ with their modified fundamental properties such as solubility, diffusivity, blood circulation half-life, drug release characteristics, and immunogenicity (Zhang et al., 2008).
Recently application of nanotechnology for drug delivery systems mainly focus on spherical nanoparticles such as calcium phosphate, gold, silver, iron oxide, polymeric micelles, liposomes, hydrogel nanoparticles and dendrimers etc. which have at least two main components, one of which is a pharmaceutically active ingredient and the other is engineered nanoparticle which may be biological origin or non-biological origin such as metals (Athar and Das, 2014). Recently more attention has been paid in the synthesis of metal nanoparticles especially silver and gold nanoparticles because metallic nanoparticles can be easily synthesized and modified that would allow them to bind with ligands, antibodies, drugs and easily delivery (Prasad $e t$ al., 2013). It has also been reported metallic nanoparticles can be easily conjugate with various biological agents such as peptides, antibodies and DNA/RNA to specifically target different cells (Sperling and Parak, 2010) with polymers and are biocompatible in vivo for drug and gene delivery 
352

(Nishiyama, 2007). They can also transform light into heat, thus enabling thermal ablation of targeted cancer cells (Chen et al., 2010) for the imaging of tumor cells and delivery of anticancer drugs (Gibson et al., 2007).

Synthesis of nanoparticles can be done by different methods such as physical, chemical, physic-chemical and biological methods (Kuila et al., 2108). Biological method of synthesis of nanoparticles is also called green synthesis which is easy, less cost effective and eco-friendly (Makarov $e t$ al., 2014). Among the metal nanoparticles synthesis of silver nanoparticles is quite easy without using or formation of any toxic chemical in the synthesis protocol and biological method of synthesis of nanoparticles are mediated by plant extract, bacteria, fungi, yeast, blue green algae and biological particles such as viruses, proteins, peptide etc. (Korbekandi et al., 2012; Iravani et al., 2014).

Metallic nanoparticles shows toxicity due to their minute size and they penetrate the basic biological structures, disrupting their normal functions such as include tissue inflammation, increased production of reactive oxygen species and cell damage and death (Zoroddu et al., 2014). Two major risks of nanoparticles to produce toxicity are that they can cross tissue junctions and even cellular membranes and accumulate in specific organs, such as the liver, spleen, myeloid tissue etc. (Albanese et al., 2012). In recent decade use of silver nanoparticles has explored due to its powerful anti-microbial and light-weight, small size and other characteristics however its safety is continuously debated for therapeutic use in drug delivery system (Holsapple et al., 2005; Shin et al., 2015). It has also been reported that silver is used as therapeutic agent for long time and recent researches reported silver nanoparticles induce toxicity in various cancer cell lines (Sambale et al., 2015).

Ganoderma applanatum is a polypore macrofungi with hard and woody fruiting body (Niemela and Miettinen, 2008). Macrofungi belong to genus Ganoderma has been traditionally used as medicine rather than fodder in China, Japan and India for therapy of various diseases (Wasser, 2011).

Present study was carried out to synthesis of SNPs mediated by $G$. applanatum extract, their characterization and toxicity impacts on body weight (BW), organ weight (OW) and blood profile of normal albino rats because toxicity impact of SNPs on mammalian model has been least explored.
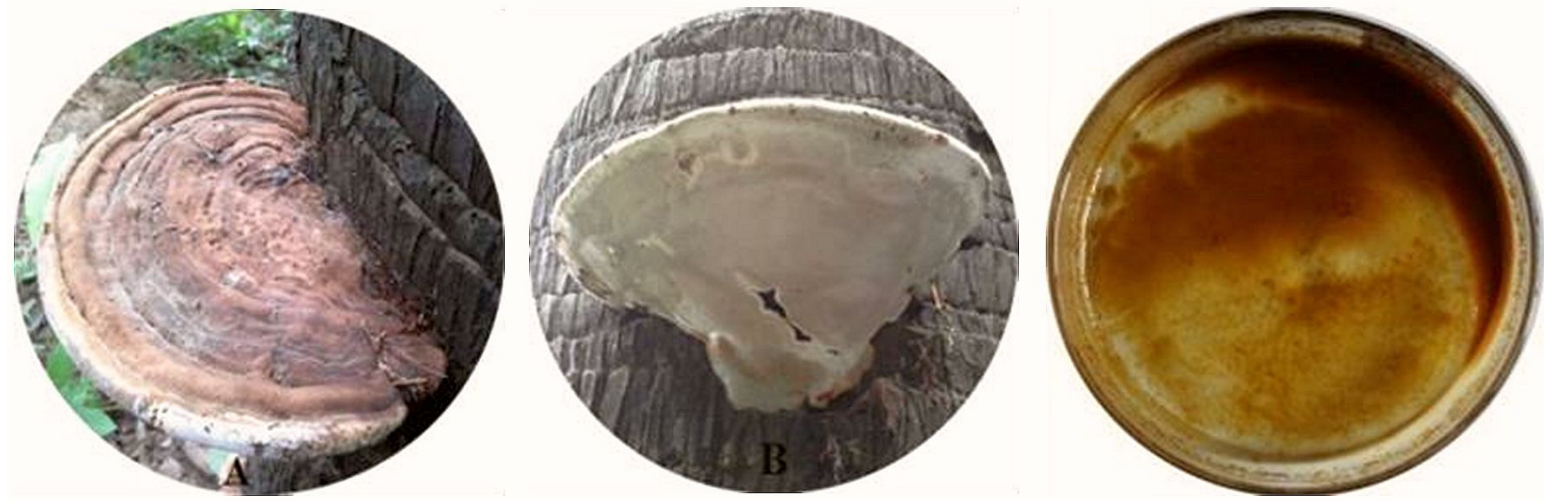

\section{Collection of macrofungi}

Fresh fruiting body of G. applanatum (presented in Fig. 1) was collected from Kaziranga National Park of Assam $\left(26^{\circ} 30^{\prime} \mathrm{N}-26^{\circ} 45^{\prime} \mathrm{N}\right.$ to $\left.93^{\circ} 08^{\prime} \mathrm{E}-93^{\circ} 36^{\prime} \mathrm{E}\right)$ and was match and identified on the basis of morphology with museum specimen by Plant Identification and Preservation Division of Department of Botany, Gauhati University, Assam where a voucher specimen (No. $833 \mathrm{M}$ ) was deposited and another fruiting body of $G$. applanatum brought to Department of Zoology, Ranchi University, Ranchi for further studies.

\section{Preparation of extrac}

The fresh fruiting bodies of $G$. applanatum were initially washed by distilled water and then by absolute ethyl alcohol (99.8\%) to avoid microbial contamination. The mushrooms were dried in shade under room temperature for six to seven days, powdered and sieved. Fifty $(50) \mathrm{g}$ of the fine powder was subjected to extraction chamber of Soxhlet and $300 \mathrm{~mL}$ distilled water was taken in boiling flask as extraction solvent for aqueous extraction. The extract obtained was filtered, concentrated and dried in rotary flash evaporator maintained at $45^{\circ} \mathrm{C}$ for proper dehydration and the dried extracts were stored in air tight containers at room temperature for further studies (Dandapat et al., 2015a).

\section{Mycochemical analysis}

Freshly prepared extract was used for mycochemical analyses. Presence of various biochemicals in the aqueous extract of $G$. applanatum was analysed followed protocols described by Arya et al. (2012) and co-worker.

\section{Biosynthesis of nanoparticles}

The synthesis of silver nanoparticles (SNPs) was done slight modification of previous method of Dandapat et al. (2014), Kumar and Sinha (2017). Synthesis of nanoparticles were done by mixed $3 \mathrm{~mL}(41 \mathrm{mg} / \mathrm{mL})$ of $G$. applanatum fruiting body aqueous extract and $197 \mathrm{~mL}$ of $0.1 \mathrm{M}$ silver nitrate $(169.87 \mathrm{~g} / \mathrm{mol})$ solution (i.e., $3.35 \mathrm{~g}$ $\mathrm{AgNO}_{3}$ in $197 \mathrm{~mL}$ of distilled water) and incubated by using hot magnetic stirrer bar at $80^{\circ} \mathrm{C}$, until the light yellow colour of the solution was changed to dark brown.

Fig. 1. Fruiting body of G. applanatum (A and B) and extract (C) 
Then the solution was cooled to room temperature and centrifuged at $15000 \mathrm{rpm}$ for 10 minutes. The supernatant was discarded and the pellet was washed with distilled water and was dried in the incubator at room temperature for characterization.

\section{Characterization of synthesized SNPS}

Synthesized SNPs were characterization by UV-Visible spectroscopy (UV-Vis), scanning electron microscopy (SEM), X-Ray diffraction analysis (XRD), dynamic light scattering (DLS) analysis and Fourier transform infrared spectroscopy (FTIR) described below.

\section{$U V$-Vis spectra analysis of SNPs}

SNPs sample for UV-Vis spectra analysis was prepared by dilute $1 \mathrm{~mL}$ of pure SNPs solution in $4 \mathrm{~mL}$ of deionized water and $1 \mathrm{~mL}$ of diluted sample was taken in standard quartz cuvette and placed in sample compartment. UVVisible spectra analysis was done by using Parkin Elmer Lambda-25 UV-Visible spectrophotometer (PerkinElmer Inc., USA). The UV-Visible spectrophotometer was operated at $240 \mathrm{~V}, 20 \pm 2{ }^{\circ} \mathrm{C}, 60-70 \%$ humidity and light test specification at 200-800 $\mathrm{nm}$ wave length (Kumar et al., 2018).

\section{SEM analysis of SNPs}

Scanning electron microscopy was done using JEOL JSM-6390 LV (Japan) machine provided with Vega TC software. Thin layer of nanoparticles powder sample $(1 \mathrm{mg})$ was prepared on glass slide and then press on a carbon taped copper grid for SEM. Excess powder on surface of carbon taped copper grid was blown away with compressed air and the SEM grid was allowed to dry by putting it under a mercury lamp for $5 \mathrm{~min}$ and was coated with platinum using ion sputter (Bini et al., 2018).

$X R D$ analysis of $S N P$ s

$\mathrm{XRD}$ analysis of the prepared sample of nanoparticles was done using a Rigaku-smartlab powered diffraction XRD machine with $40 \mathrm{kV}$ operating voltage and $15 \mathrm{~mA}$ current, $\mathrm{Cu}-\mathrm{K} \alpha \mathrm{X}$-rays of wavelength $(\lambda)=1.54056 \AA$ and data was taken for the $2 \theta$ range of $10^{\circ}$ to $90^{\circ}$ with a step of $0.02^{\circ}$. The particle size was calculated by considering the peak at degrees and by using Debye-Scherrer formula (Kumar and Rao, 2013).

$$
\mathrm{D}=\frac{0.9 \lambda}{\beta \cos \theta} \text {. }
$$

Where, $\lambda$ ' is wave length of $X$-Ray $(0.1541 \mathrm{~nm})$, ' $\beta$ ' is FWHM (full width at half maximum), ' $\theta$ ' is the diffraction angle and ' $D$ ' is particle diameter size.

\section{$D L S$ analysis of SNPs}

The sample was diluted, filtered and $0.1 \mathrm{mg} / \mathrm{mL}$ concentration of SNPs colloidal solution was ultrasonicated at $20 \%$ sonication amplitude with continuous mode during 882 second to avoid agglomeration and for proper dispersion of nanoparticles in the solution. The dynamic light scattering for particle size and zeta potential analysis of nanoparticles was carried out using Malvern Nano ZS green badge) ZEN3500 (U.K.) zeta sizer provided with zetasizer Nano software (ZNUM, 2013).
FTIR spectra analysis of SNPS

FTIR spectra analysis was carried out IPR resting-21 (Shimadzu Corp., Kyoto, Japan) in the diffuse reflectance mode operated at $4 \mathrm{~cm}^{-1}$ in the range of $400 \mathrm{~cm}^{-1}$ to 4000 $\mathrm{cm}^{-1}$ wave number and $\mathrm{KBr}$ as standard to identify the potential biomolecules present in fruiting body of $G$. applanatum extract which are responsible for reducing and capping the bio reduced $G$. applanatum extract mediated SNPs. The FTIR machine was operated at $25 \pm 5{ }^{\circ} \mathrm{C}, 60$ $70 \%$ humidity and $240 \mathrm{~V} \mathrm{AC} \mathrm{(IMUSG,} \mathrm{2002).}$

\section{Toxicity of silver nanoparticles \\ Animals}

Wistar albino rats (Ratus norvegicus) of mass between 175 to $200 \mathrm{~g}$ were obtained from the National Institute of Nutrition, Hyderabad, India. They were maintained under standard laboratory conditions at ambient temperature of $25 \pm 2{ }^{\circ} \mathrm{C}$ and relative humidity at $50 \pm 15 \%$, with darklight cycle of $12 \mathrm{~h}$. Animals were fed with a commercial pallet diet (Sadguru Shri Shri Industries Pvt. Ltd. Pune, India) and water. The experiment was performed after prior approval of the Ethics committee of Ranchi University, Ranchi (Proceeding no. 46, page no. 137).

\section{Acute toxicity study}

According to OECD test guideline 425 (Up and Down procedure) limited test for $G$. applanatum extract mediated SNPs was performed at the test dose $2000 \mathrm{mg} / \mathrm{kg}$. Ten (10) rats were equally divided into two groups ( $\mathrm{A}$ and $\mathrm{B}$ ) and were fasted (3-4 hours) prior to dosing but were accessed with water ad libitum. Single dose $(2000 \mathrm{mg} / \mathrm{kg})$ of $G$. applanatum extract mediated SNPs and vehicle (distilled water) were administrated to single animals of each group by gavage using stomach tube and rats were provided with food and water ad libitum after 2 hours. Similarly 4 other rats of each group were treated with $G$. applanatum extract mediated SNPs and vehicle (OECD, 2008a; Saleem et al., 2017). Animals were observed for clinical symptoms of toxicity and mortality during the treatment period (8 days), the initial body weight (IBW), final body weights (FBW) and weight of vital organs (OW) of animals of both the groups were recorded.

\section{Sub-acute toxicity of silver nanoparticles}

Sub-acute toxicity of the SNPs was evaluated on Wistar albino rats as per the Organization for Economic Cooperation and Development (OECD) guidelines with slight modification (Njoya et al., 2008; OECD, 2008b). Fifteen fresh male rats were distributed among three treatment groups (Group: 1, 2 and 3) and each group contains 5 animals. The animals were received single dose vehicle, high and low of SNPs daily for 7 days as described below.

Group-1: Rats of this group serve as control and were received $1 \mathrm{~mL}$ distilled water orally for 7 days.

Group-2: Rats of this group were received $200 \mathrm{mg} \mathrm{kg}^{-1}$ body weight (low dose: LD) of G. applanatum extract mediated SNPs orally for 7 days.

Group-3: Rats of this group were received orally $400 \mathrm{mg}$ $\mathrm{kg}^{-1}$ body weight (high dose: HD) of G. applanatum extract mediated SNPs orally for 7 days. 
354

Animals were observed for clinical symptoms of toxicity during the treatment period (for 7 days), and the body weights of animals were recorded before blood collection by retro-orbital sinus blood collection method. At the end of the treatment $\left(8^{\text {th }}\right.$ day), animals were fasted overnight, but allowed free access to water. These animals were anesthetized with ether and were sacrificed by cervical dislocation for the collection vital organs such as heart, liver, kidney, heart and testis. OWs of treatment groups were calculated and compared with the OW of the control group animals.

\section{Impact of silver nanoparticles on blood profile rat}

For hematological indices, blood samples were collected into sterile tubes containing EDTA and immediately

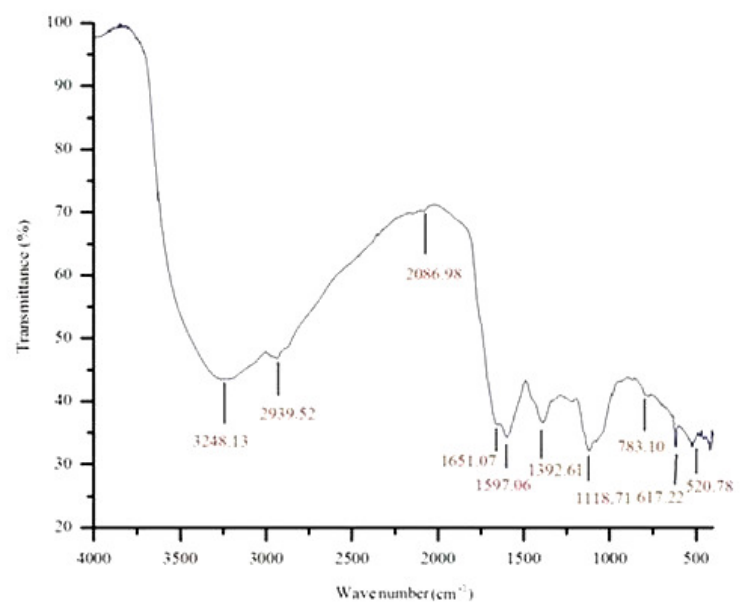

analysed for TWBC, RBC, HB, PCV, MCV, MCH, MCHC, PLT and LYM using Sysmex automated blood analyser - KX 21 Kobe, Japan.

\section{Results}

The collected fruiting body of $G$. applanatum, cultured mycelia and extract obtained is presented in Fig. 1. The collected basediocarp was semi-circular in shape, $13 \mathrm{~cm}$ in diameter. Outer surface of carp having wrinkled zones of brownish to greyish-brown colour and the lower surface is white.

\section{Mycochemicalscreening}

Result of mycochemical screening is presented in Table 1. In the present study different mycochemicals such as carbohydrate, protein, alkaloid, flavonoid, saponins, steroid, phenolics etc. were found in the aqueous extract of fruiting body of $G$. applanatum.

\section{FTIR spectra analysis of G. applanatum extract}

FTIR spectroscopy spectra of $G$. applanatum extract is presented in Fig. 2. FTIR spectroscopy analysis of $G$. applanatum extract showed major transmittance peaks at $3248.13 \mathrm{~cm}^{-1}$ for phenol O-H stretch, $2939.52 \mathrm{~cm}^{-1}$ for alkyl C-H stretch, $2086.98 \mathrm{~cm}^{-1}$ for terminal alkyne $\mathrm{C} \equiv \mathrm{C}$ stretch, $1651.07 \mathrm{~cm}^{-1}$ for amide $\mathrm{C}=\mathrm{O}$ stretch, $1597.06 \mathrm{~cm}^{-1}$ for primary amine $\mathrm{N}-\mathrm{H}$ stretch, $1392.61 \mathrm{~cm}^{-1}$ for fluro alkane C-F stretch, $783.10 \mathrm{~cm}^{-1}$ for aromatic (metadisub bengene) $\mathrm{C}-\mathrm{H}$ stretch, $617.22 \mathrm{~cm}^{-1}$ for chloro akane $\mathrm{C}-\mathrm{Cl}$ stretch and $520.78 \mathrm{~cm}^{-1}$ for bromo alkane $\mathrm{C}-\mathrm{Br}$ stretch.

Table 1. Screening of proximate mycochemicals present in aqueous fruiting body extract of $G$. applanatum

\begin{tabular}{ccc}
\hline Mycochemicals & Present $(+)$ or Absent $(+)$ \\
\hline Carbohydrate & + \\
Glycosides & + \\
Protein & + \\
Alkaloid & + \\
Steroid & + \\
Triterpene & + \\
Flavonoid & + \\
Tannin & + \\
Lipid & + \\
Saponin & + \\
\hline
\end{tabular}

\section{Synthesis and characterization of SNPs}

Synthesis of silver nanoparticles mediated by aqueous fruiting body extract solution is presented in Fig. 3. Result showed the change of pale yellow colour of mixed solution of extract and $\mathrm{AgNO}_{3}$ solution turns into dark brown as the temperature and incubation time period increase, which indicates the formation of nanoparticles.

\section{$U V$-Visible spectroscopy analysis}

The absorption spectrum of nanoparticles obtained from UV-visible absorption spectroscopy is presented in Fig. 4, which shows peak at $400 \mathrm{~nm}$ corresponds to the surface plasmon resonance.

\section{Scanning electron microscopy (SEM) analysis}

Scanning electron microscopy provided the confirmation about the morphology of synthesized green nanoparticles. Result of SEM analysis is presented in Fig. 5, which showed the synthesized nanoparticles are spherical shaped and size ranges from $70 \mathrm{~nm}$ to $120 \mathrm{~nm}$ in diameter.

\section{$X$-ray diffraction analysis}

The information pertaining to phase formation, translational symmetry present and size and shape of the unit cell are obtained from peak positions in the diffraction pattern of a sample. The X-ray diffraction pattern of the $G$. applanatum extract mediated synthesized SNPs are shown 
in Table 2 and Fig. 6. The result showed particles of 60.60 $\mathrm{nm}$ to $121.19 \mathrm{~nm}$ were formed with average particle size $102.08 \mathrm{~nm}$. The diffraction pattern has been analysed and refined using open source full proof analysis software. It consists of the major peaks of silver nanoparticles with fcc type lattice and some additional unassigned peaks, which may be attributed to the formation of bio-organic phase acting as surfactant for the silver nanoparticles.

Table 2. Average size estimation of $G$. applanatum extract mediated nanoparticles using X-ray diffraction analysis of and using Scherrer formula

\begin{tabular}{ccccccccc}
\multicolumn{8}{c}{ Copper K radiation: Wavelength $\lambda(\mathrm{nm})=0.154$} \\
\hline $\begin{array}{c}2 \theta \text { of the } \\
\text { major } \\
\text { peaks } \\
(\text { deg. })\end{array}$ & $\begin{array}{c}\theta \text { of the } \\
\text { peak } s\end{array}$ & $\begin{array}{c}\text { d-spacing } \\
(\text { deg. })\end{array}$ & $\begin{array}{c}\text { Intensity } \\
(\text { cps })\end{array}$ & $\begin{array}{c}\text { FWHM of } \\
\text { major peaks } \\
(\beta \text { : deg. })\end{array}$ & $\begin{array}{c}\text { FWHM of } \\
\text { the major } \\
\text { peaks } \\
(\beta: \text { rad. })\end{array}$ & $\begin{array}{c}\text { Size } \\
(\AA)\end{array}$ & $\begin{array}{c}\text { Size } \\
(\mathrm{nm})\end{array}$ & $\begin{array}{c}\text { Avg. Size } \\
(\mathrm{nm})\end{array}$ \\
\hline 35.51 & 17.75 & 2.52581 & 9732.26 & 0.0796 & 0.0013 & 1093.7 & 109.37 \\
29.66 & 14.83 & 3.00943 & 1690.34 & 0.0732 & 0.0012 & 1171.7 & 117.17 & 102.08 \\
21.73 & 10.86 & 4.08588 & 1652.76 & 0.1393 & 0.0024 & 606.0 & 60.60 & 121.19 \\
75.09 & 37.54 & 1.26401 & 1411.44 & 0.0863 & 0.0015 & 1211.9 & \\
\hline
\end{tabular}

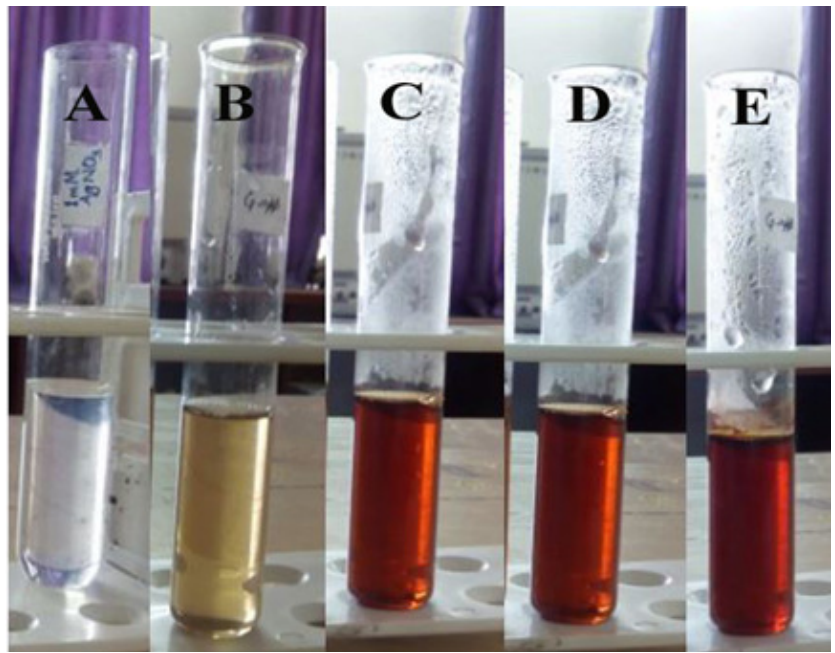

Fig. 3. Change in colour of mixed solution: (A) $\mathrm{AgNO}_{3}$ solution; (B) $\mathrm{AgNO}_{3}$ solution and extract at room temperature; C, D and E-mixed solution after heat stirring of 30 minutes, 1 hour and 2 hours respectively

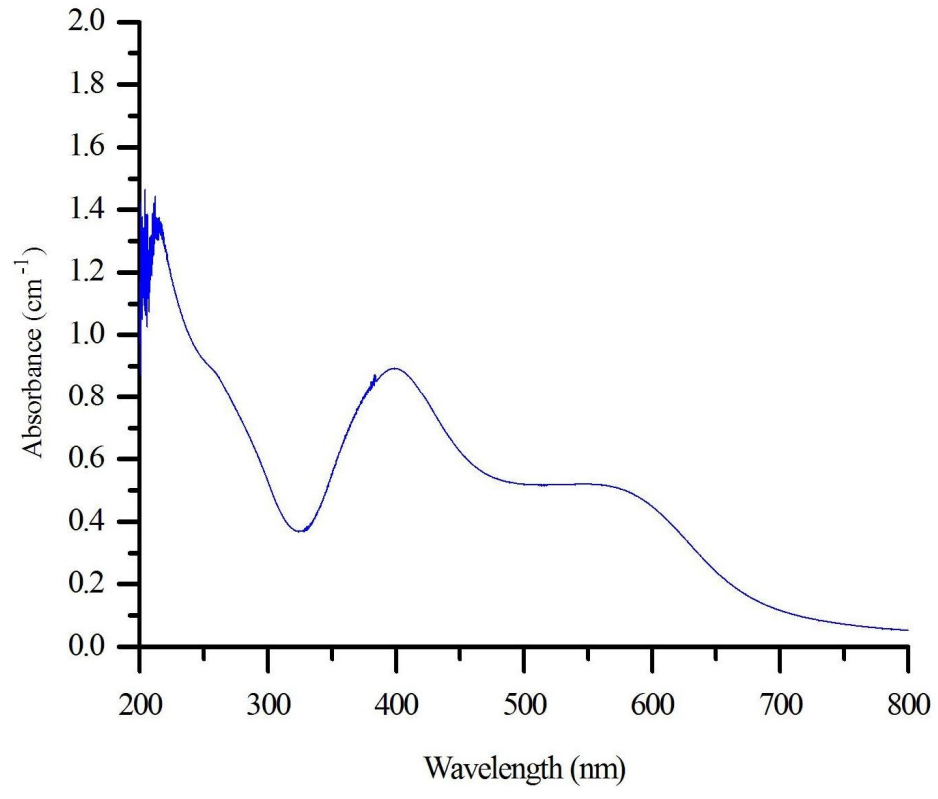

Fig. 4. UV-Visible spectrum of synthesized SNPs mediated by aqueous fruiting body extract of G. applanatum 

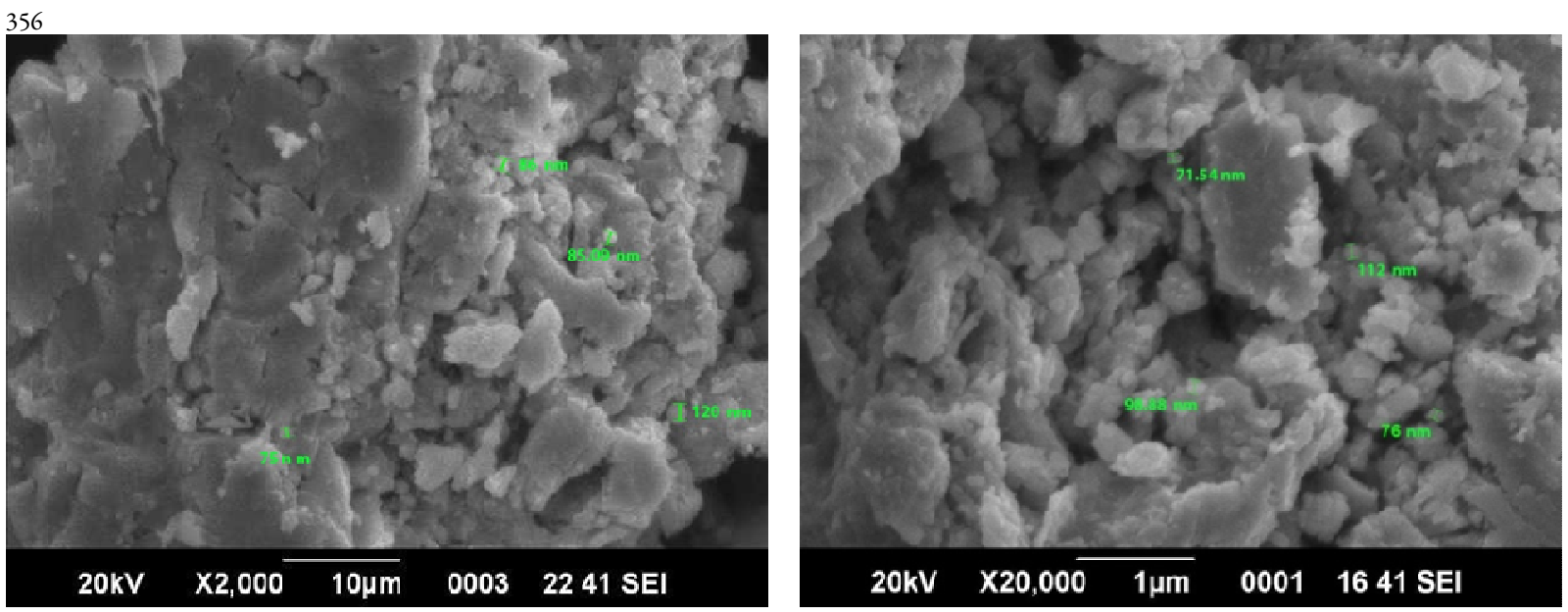

Fig. 5. Scanning electron microscopy photograph of SNPs mediated by aqueous fruiting body extract of G. applanatum

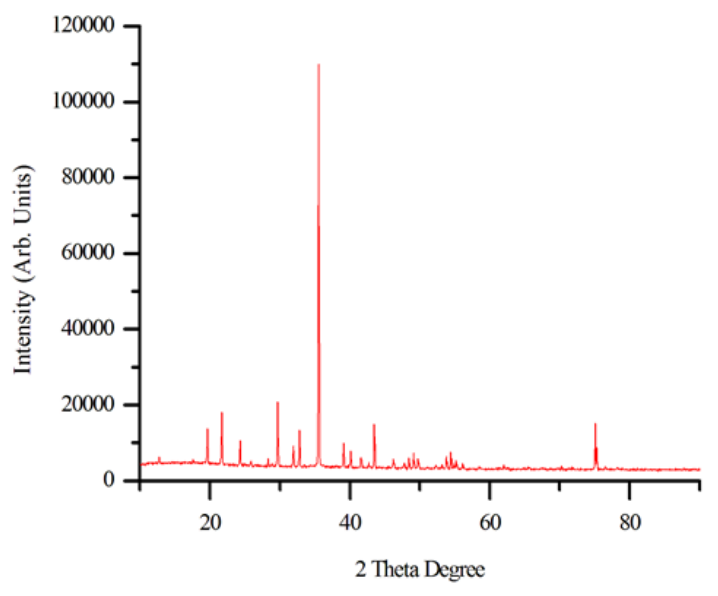

Fig. 6. X-Ray diffraction peaks of $G$. applanatum extract mediate nanoparticles powder

\section{Dynamic light scattering (DLS) analysis}

Size and distribution of nanoparticles play a fundamental role in quality control of nanoparticles synthesis. It also basically associated diffusivity and passage of nanoparticles through cell membranes in the field of nano biotechnology. In the present study size distributions of number, intensity, volume and zeta potential of synthesized $G$. applanatum extract mediated nanoparticles were analysed by DLS method. The results of DLS analysis are presented in Figs. 7, 8, 9 and Table 3. Result of zeta potential analysis if SNPs is presented in 10 and 11 (hypothetical figure).

Cumulants mean (Z-average) obtained by DLS analysis for the synthesized silver nanoparticle is 58.78 d.nm corresponds to average size in diameter. Fig. 7 (particle size distribution by intensity) represents high peak for nanoparticles of $77.25 \mathrm{~nm}$ diameters with $99.6 \%$ intensity and small peak for $5177 \mathrm{~nm}$ diameter nanoparticles with $3.4 \%$ intensity. Fig. 8 (particle size distribution by volume) represents high peak and low peak for nanoparticles of $88.4 \%$ and $11.3 \%$ size distribution by volume of $38.21 \mathrm{~nm}$ and $5282 \mathrm{~nm}$ diameter nanoparticles respectively. Fig. 9 (particle size distribution by number) represents single peak for nanoparticles of diameter of $23.64 \mathrm{~nm}$ with $100 \%$ size distribution by number. Total Number of SNPs with their respective size distribution also revealed that, the SNPs were distributed evenly in the in sample solution (Table 3). Zeta potential is the electrostatic charge distribution, develops in liquid layer or capping materials on surface presented in Fig. 10. In present study the zeta potential analysis of nanoparticles provides peak at $-13.8 \mathrm{mV}$ potential with $100 \%$ area distribution, presented in Fig. 11.

\section{FTIR analysis of SNPs}

In the present study FTIR analysis of silver nanoparticles synthesized from $G$. applanatum extract is presented in Fig. 12. The result represents absorption peaks at $3606 \mathrm{~cm}^{-1}$ corresponds to O-H stretch for alcohol and phenol, 2430 $\mathrm{cm}^{-1}$ corresponds to $\mathrm{N}-\mathrm{H}$ stretch for primary and secondary amines, $2156 \mathrm{~cm}^{-1}$ corresponds to $\mathrm{C} \equiv$ stretch for alkynes, $1681 \mathrm{~cm}^{-1}$ corresponds to $\mathrm{C}=\mathrm{N}$ for amines or $\mathrm{C}=\mathrm{O}$ stretch for unsaturated aromatic carboxylic acid, $1234 \mathrm{~cm}^{-1}$ corresponds to C-O stretch for aromatic compound, 1091 $\mathrm{cm}^{-1}$ corresponds to C-F stretch for fluroalkanes, $925 \mathrm{~cm}^{-1}$ corresponds to $\mathrm{C}=\mathrm{C}$ stretch foralkanes and also stretch for $\mathrm{O}-\mathrm{H}$ and $613 \mathrm{~cm}^{-1}$ corresponds to $\mathrm{C}-\mathrm{Cl}$ or $\mathrm{C}-\mathrm{Br}$ stretch for chloro and bromo alkanes.

\section{Acute and sub-acute toxicity effect of SNPs}

Results of acute toxicity of SNPs are presented in Tables 3 and 4 . The results showed no mortality was observed in rats of vehicle and SNPs treated rats at $2000 \mathrm{mg} / \mathrm{kg}$ dose. Behavioral observation of the test animals after dosing showed elevated respiration rate and sleeping for first 30 min (Table 4). However, no other behavioural changes such as convulsions, tremors, itching, shivering, somatomotor activity etc. were observed in the animals group treated with SNPs (Table-4) for 4 hours, 24 hours and 7 days. Result acute toxic impact of SNPs on body weight and organ weight is presented in Table 5. The results showed that, final BW of rats significantly $(p<0.05)$ increased compare to initial $\mathrm{BW}$ of rats treated with extract and final BW of rats treated with vehicle. A non-significant increase in weight of liver, kidneys, lungs and heart of rats treated with SNPs compare to vehicle treated group. However, significant $(\mathrm{p}<0.05)$ decrease in weight of testes was observed in SNPs treated groups compare to vehicle treated group. 
Size Distribution by Intensity

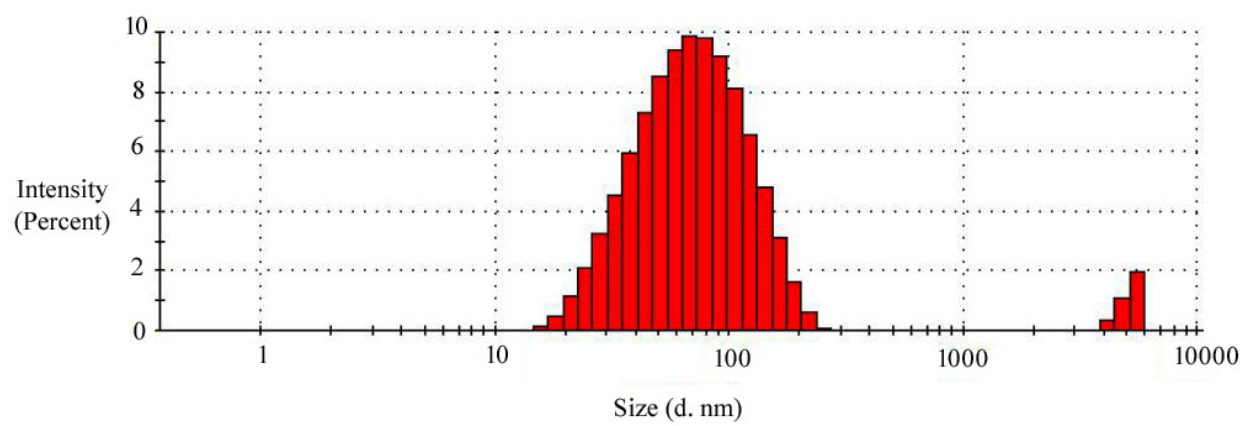

Fig. 7. DLS size distribution by intensity of G. applanatum extract mediate SNPs

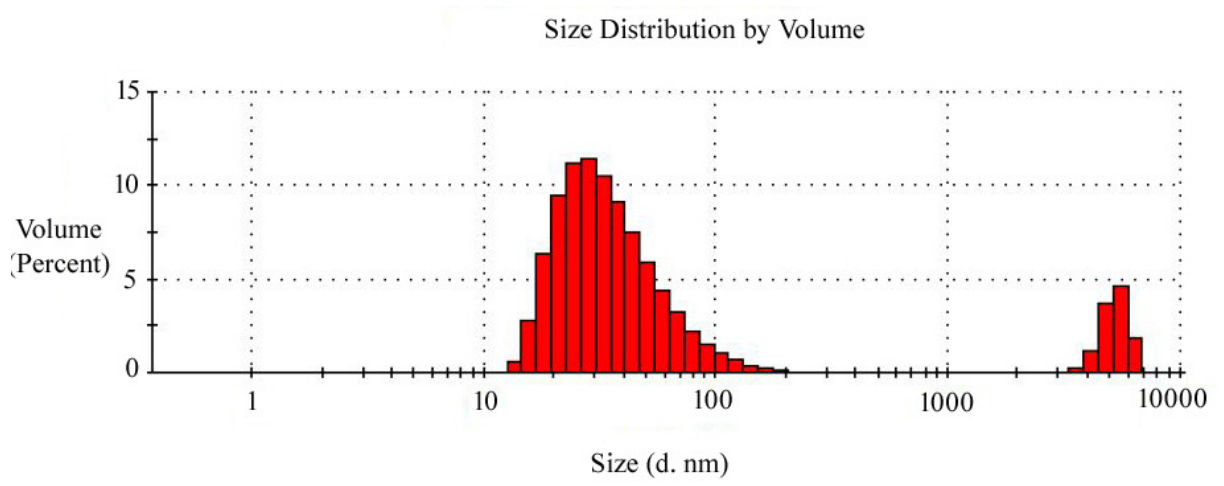

Fig. 8. DLS size distribution by volume of $G$. applanatum extract mediate SNPs

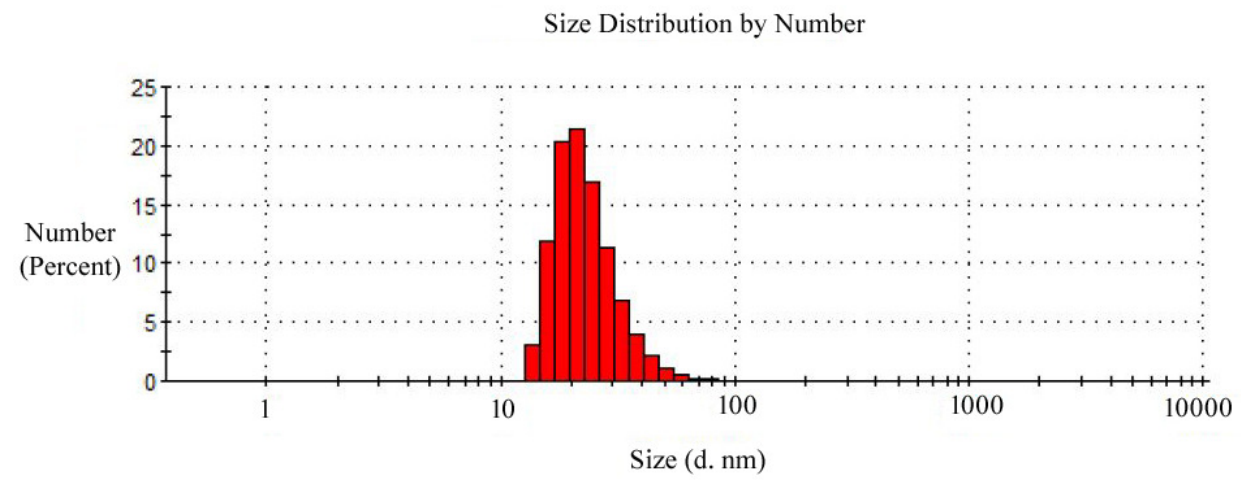

Fig. 9. DLS size distribution by number of $G$. applanatum extract mediate SNPs

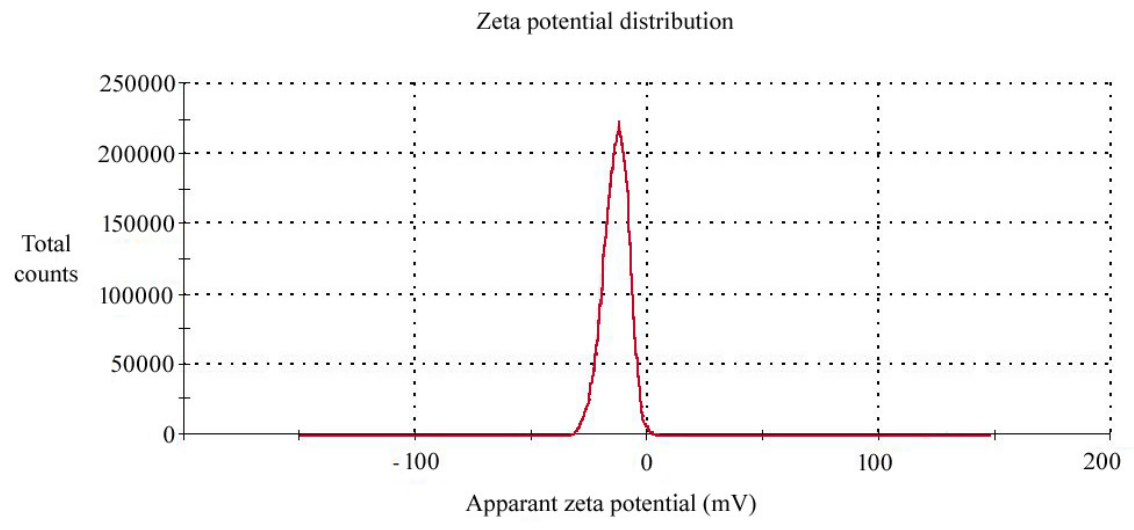

Fig. 10. DLS zetapotential of G. applanatum extract mediate SNPs 


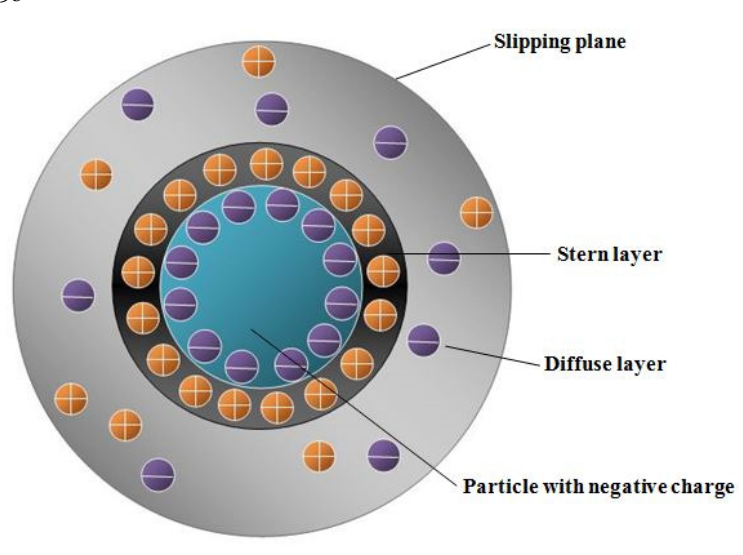

Fig. 11. Dielectric potential exists at the boundary of a SNP (Ztasizernano user manual, 2013; Haider and Kang, 2015)

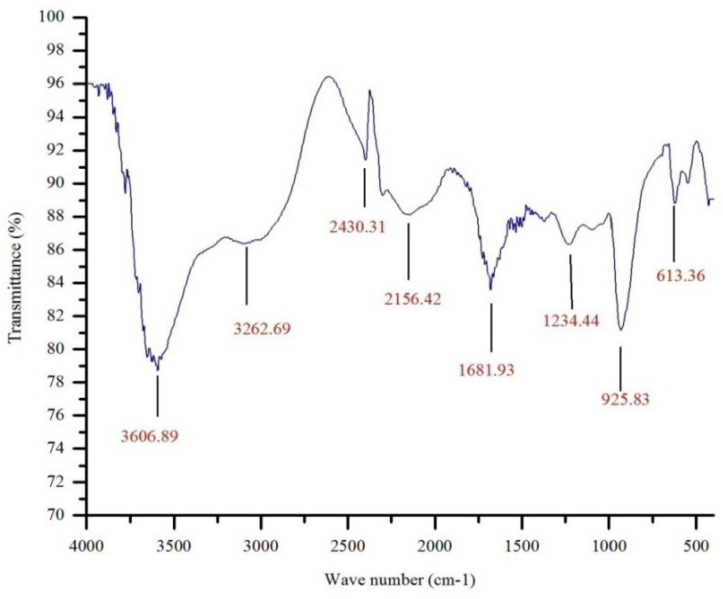

Fig. 12. FTIR sperta of $G$. applanatum extract mediated silver nanoparticles

Table 3. Size distribution report of synthesized nanoparticles by intensity, by volume and by number

\begin{tabular}{|c|c|c|c|c|}
\hline \multicolumn{5}{|c|}{ Size distribution by intensity } \\
\hline Peaks & Size (d. nm) & \% Intensity & St Dev. (d. nm) & Z-Average (d. nm) \\
\hline 1 & 77.25 & 96.6 & 40.37 & \multirow{2}{*}{58.78} \\
\hline 2 & 5177 & 3.4 & 487.1 & \\
\hline \multicolumn{5}{|c|}{ Size distribution by volume } \\
\hline Peaks & Size (d. nm) & $\%$ Volume & St Dev. (d. nm) & Z-Average (d. nm) \\
\hline 1 & 38.21 & 88.4 & 23.11 & \multirow{2}{*}{58.78} \\
\hline 2 & 5282 & 11.6 & 711.5 & \\
\hline \multicolumn{5}{|c|}{ Size distribution by number } \\
\hline Peaks & Size (d. nm) & $\%$ Number & St Dev. (d. nm) & Z-Average (d. nm) \\
\hline 1 & 23.64 & 100 & 8.379 & 58.78 \\
\hline
\end{tabular}

Table 4. Behavioural symptoms of rats treated with vehicle and SNPs $2000 \mathrm{mg} / \mathrm{kg}$. N=nontoxic effect, I=increase, NF=not found

\begin{tabular}{|c|c|c|c|c|c|c|c|c|}
\hline \multirow{3}{*}{ Groups of rats } & \multicolumn{4}{|c|}{ Group-A } & \multicolumn{4}{|c|}{ Group-B } \\
\hline & $30 \mathrm{Min}$. & $4 \mathrm{Hrs}$. & $24 \mathrm{Hrs}$. & 7 Days & $30 \mathrm{Min}$. & $4 \mathrm{Hrs}$. & $24 \mathrm{Hrs}$. & 7 Days \\
\hline & & & & & & & & \\
\hline Fur \& skin & $\mathrm{N}$ & $\mathrm{N}$ & $\mathrm{N}$ & $\mathrm{N}$ & $\mathrm{N}$ & $\mathrm{N}$ & $\mathrm{N}$ & $\mathrm{N}$ \\
\hline Eyes & $\mathrm{N}$ & $\mathrm{N}$ & $\mathrm{N}$ & $\mathrm{N}$ & $\mathrm{N}$ & $\mathrm{N}$ & $\mathrm{N}$ & $\mathrm{N}$ \\
\hline Salivation & $\mathrm{N}$ & $\mathrm{N}$ & $\mathrm{N}$ & $\mathrm{N}$ & $\mathrm{N}$ & $\mathrm{N}$ & $\mathrm{N}$ & $\mathrm{N}$ \\
\hline Breathing & I & $\mathrm{N}$ & $\mathrm{N}$ & $\mathrm{N}$ & I & $\mathrm{N}$ & $\mathrm{N}$ & $\mathrm{N}$ \\
\hline $\begin{array}{c}\text { Somatomotor } \\
\text { activity \& } \\
\text { behavior pattern }\end{array}$ & $\mathrm{N}$ & $\mathrm{N}$ & $\mathrm{N}$ & $\mathrm{N}$ & $\mathrm{N}$ & $\mathrm{N}$ & $\mathrm{N}$ & $\mathrm{N}$ \\
\hline Sleep & $\mathrm{N}$ & $\mathrm{N}$ & $\mathrm{N}$ & $\mathrm{N}$ & I & $\mathrm{N}$ & $\mathrm{N}$ & $\mathrm{N}$ \\
\hline $\begin{array}{c}\text { Convulsions \& } \\
\text { tremors }\end{array}$ & $\mathrm{NF}$ & NF & $\mathrm{NF}$ & $\mathrm{NF}$ & $\mathrm{N}$ & $\mathrm{N}$ & $\mathrm{N}$ & $\mathrm{N}$ \\
\hline Itching & $\mathrm{NF}$ & NF & $\mathrm{NF}$ & $\mathrm{NF}$ & $\mathrm{NF}$ & NF & $\mathrm{NF}$ & $\mathrm{NF}$ \\
\hline Coma & $\mathrm{NF}$ & $\mathrm{NF}$ & NF & NF & $\mathrm{NF}$ & NF & $\mathrm{NF}$ & $\mathrm{NF}$ \\
\hline Death & $\mathrm{NF}$ & NF & $\mathrm{NF}$ & $\mathrm{NF}$ & NF & NF & $\mathrm{NF}$ & $\mathrm{NF}$ \\
\hline
\end{tabular}


Table 5. Organ weight and body weight of rats treated with vehicle and SNPs $2000 \mathrm{mg} / \mathrm{kg} . \mathrm{n}=5 \pm \mathrm{SE}$ of mean, $\mathrm{a}=\mathrm{p}<0.05, \mathrm{~b}=\mathrm{p}<0.025, \mathrm{c}=\mathrm{p}<0.005$

\begin{tabular}{|c|c|c|}
\hline$x_{2}$ & Group-A & Group-B \\
\hline \multicolumn{3}{|l|}{$\mathrm{BW}$ and $\mathrm{OW}(\mathrm{g})$} \\
\hline Initial BW & $178.61 \pm 1.58$ & $181.14 \pm 1.47$ \\
\hline Final BW & $181.58 \pm 1.16$ & $185.10 \pm 0.90^{a, b}$ \\
\hline Liver & $5.52 \pm 0.38$ & $4.87 \pm 0.37$ \\
\hline Kidneys & $1.60 \pm 0.13$ & $1.56 \pm 0.12$ \\
\hline Heart & $0.78 \pm 0.04$ & $0.79 \pm 0.04$ \\
\hline Lungs & $0.93 \pm 0.09$ & $0.93 \pm 0.09$ \\
\hline Testes & $2.42 \pm 0.11$ & $1.94 \pm 0.05^{c}$ \\
\hline
\end{tabular}

Effect of $L D$ and HD of SNPs on body weight, organ weight and behavior

Results of $G$. applanatum extract mediated SNPs on BW, OW and behaviour are presented in Table 6 and 7 . The results showed final BW of rats treated with extract significantly $(p<0.05)$ increased compare to initial BW of rats treated with $\mathrm{LD}$ and $\mathrm{HD}$ of SNPs.

Effect of $L D$ and HD of SNPs on hematological parameters

Effect of G. applanatum extract mediated SNPs on hematological profile of rats is presented in Table 8. The results showed SNPs non-significantly elevated $\mathrm{RBC}, \mathrm{Hb}$, PCV, MCV and MCHC. SNPs significantly $(p<0.05)$ elevated WBC, neutrophil and lymphocyte count in LD and HD treatment groups compare to control group. $G$. applanatum extract mediated SNPs significantly $(\mathrm{p}<0.05)$ elevated platelet count in HD treatment group compare to control group.

\section{Discussion}

Mushrooms are also called as macrofungi possess high antioxidant activity and therapeutic efficacy due to their synthesized antioxidant compounds such as phenolics, organic acids, alkaloids etc. derived by saprophytic metabolism and the mushrooms can be used as a fodder and in the pharmaceutical industry (Menaga et al., 2012;

Table 6. Behavioural symptoms of rats treated with vehicle, SNPs $200 \mathrm{mg} / \mathrm{kg}$ and $400 \mathrm{mg} / \mathrm{kg}$. N=nontoxic effect, I=increase, NF=not found

\begin{tabular}{|c|c|c|c|c|c|c|c|c|c|c|c|c|}
\hline \multirow{3}{*}{ Groups of rats } & \multicolumn{4}{|c|}{ Group-1 } & \multicolumn{4}{|c|}{ Group-2 } & \multicolumn{4}{|c|}{ Group-3 } \\
\hline & $30 \mathrm{Min}$. & 4 Hrs. & $24 \mathrm{Hrs}$. & 7 Days & $30 \mathrm{Min}$. & $4 \mathrm{Hrs}$ & $24 \mathrm{Hrs}$. & 7 Days & 30 Min. & $4 \mathrm{Hrs}$. & $24 \mathrm{Hrs}$. & 7 Days \\
\hline & & & & & & & & & & & & \\
\hline Fur \& skin & $\mathrm{N}$ & $\mathrm{N}$ & $\mathrm{N}$ & $\mathrm{N}$ & $\mathrm{N}$ & $\mathrm{N}$ & $\mathrm{N}$ & $\mathrm{N}$ & $\mathrm{N}$ & $\mathrm{N}$ & $\mathrm{N}$ & $\mathrm{N}$ \\
\hline Eyes & $\mathrm{N}$ & $\mathrm{N}$ & $\mathrm{N}$ & $\mathrm{N}$ & $\mathrm{N}$ & $\mathrm{N}$ & $\mathrm{N}$ & $\mathrm{N}$ & $\mathrm{N}$ & $\mathrm{N}$ & $\mathrm{N}$ & $\mathrm{N}$ \\
\hline Salivation & $\mathrm{N}$ & $\mathrm{N}$ & $\mathrm{N}$ & $\mathrm{N}$ & $\mathrm{N}$ & $\mathrm{N}$ & $\mathrm{N}$ & $\mathrm{N}$ & $\mathrm{N}$ & $\mathrm{N}$ & $\mathrm{N}$ & $\mathrm{N}$ \\
\hline Breathing & I & $\mathrm{N}$ & $\mathrm{N}$ & I & I & $\mathrm{N}$ & $\mathrm{N}$ & I & I & $\mathrm{N}$ & $\mathrm{N}$ & I \\
\hline $\begin{array}{l}\text { Somatomotor } \\
\text { activity \& } \\
\text { behavior pattern }\end{array}$ & $\mathrm{N}$ & $\mathrm{N}$ & $\mathrm{N}$ & $\mathrm{N}$ & $\mathrm{N}$ & $\mathrm{N}$ & $\mathrm{N}$ & $\mathrm{N}$ & $\mathrm{N}$ & $\mathrm{N}$ & $\mathrm{N}$ & $\mathrm{N}$ \\
\hline Sleep & $\mathrm{N}$ & $\mathrm{N}$ & $\mathrm{N}$ & $\mathrm{N}$ & $\mathrm{N}$ & $\mathrm{N}$ & $\mathrm{N}$ & $\mathrm{N}$ & $\mathrm{N}$ & $\mathrm{N}$ & $\mathrm{N}$ & $\mathrm{N}$ \\
\hline $\begin{array}{l}\text { Convulsions \& } \\
\text { tremors }\end{array}$ & NF & $\mathrm{NF}$ & NF & $\mathrm{NF}$ & NF & $\mathrm{NF}$ & $\mathrm{NF}$ & NF & $\mathrm{NF}$ & NF & $\mathrm{NF}$ & NF \\
\hline Itching & NF & NF & NF & $\mathrm{NF}$ & $\mathrm{NF}$ & $\mathrm{NF}$ & $\mathrm{NF}$ & $\mathrm{NF}$ & $\mathrm{NF}$ & NF & $\mathrm{NF}$ & $\mathrm{NF}$ \\
\hline Coma & $\mathrm{NF}$ & NF & NF & $\mathrm{NF}$ & $\mathrm{NF}$ & $\mathrm{NF}$ & $\mathrm{NF}$ & $\mathrm{NF}$ & $\mathrm{NF}$ & NF & $\mathrm{NF}$ & $\mathrm{NF}$ \\
\hline Death & NF & NF & NF & NF & NF & $\mathrm{NF}$ & NF & NF & NF & NF & NF & NF \\
\hline
\end{tabular}

Table 7. Organ weight and body weight of rats treated with vehicle and SNPs 200 and $400 \mathrm{mg} / \mathrm{kg} . \mathrm{n}=5 \pm \mathrm{SE}$ of mean, a=p $<0.05$

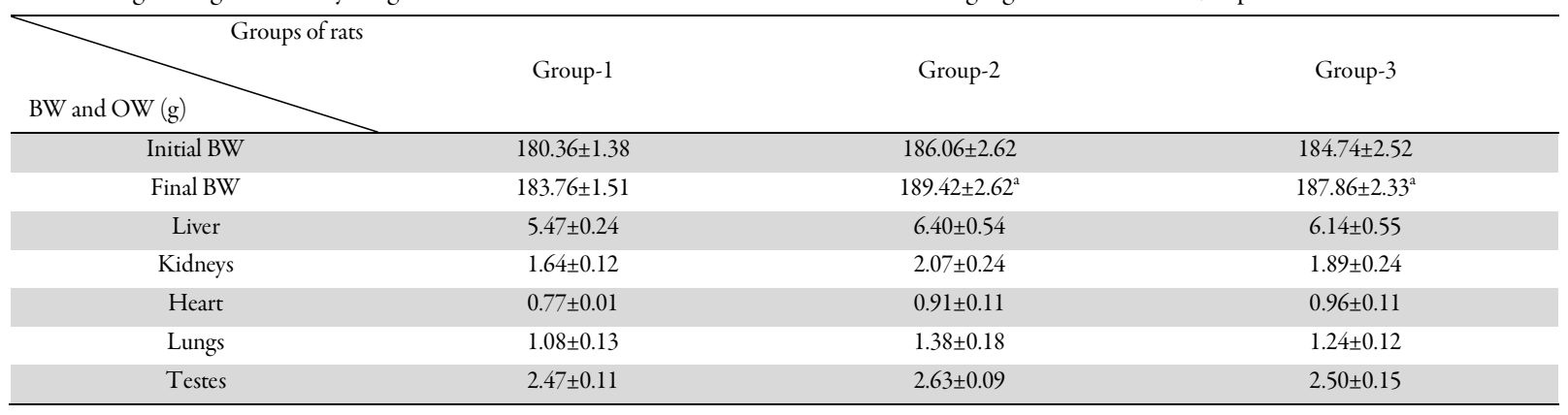


360

Table 8. Effect of SNPs on hematological profile rats treated with vehicle and SNPs 200 and $400 \mathrm{mg} / \mathrm{kg}$. $\mathrm{n}=5 \pm \mathrm{SE}$ of mean, $\mathrm{a}=\mathrm{p}<0.05, \mathrm{~b}=\mathrm{p}<0.01$, $\mathrm{c}=\mathrm{p}<0.005, \mathrm{~d}=\mathrm{p}<0.0025, \mathrm{e}=\mathrm{p}<0.0005$

\begin{tabular}{|c|c|c|c|}
\hline $\mathrm{BW}_{\mathrm{BW}}$ Grou $(\mathrm{g})$ & Group-1 & Group-2 & Group-3 \\
\hline $\operatorname{RBC} \times 10^{6} \mu \mathrm{L}^{-1}$ & $4.21 \pm 0.02$ & $4.42 \pm 0.13$ & $4.46 \pm 0.09$ \\
\hline $\mathrm{Hbg} \mathrm{dL}{ }^{-1}$ & $11.66 \pm 0.21$ & $11.70 \pm 0.31$ & $11.83 \pm 0.32$ \\
\hline PCV \% & $26.34 \pm 0.45$ & $26.66 \pm 0.46$ & $26.64 \pm 0.62$ \\
\hline MCV fL & $93.00 \pm 0.15$ & $93.01 \pm 0.15$ & $93.04 \pm 0.16$ \\
\hline $\mathrm{MCHC} \mathrm{g} \mathrm{dL}^{-1}$ & $23.71 \pm 0.16$ & $23.86 \pm 0.18$ & $24.02 \pm 0.15$ \\
\hline WBC X $10^{3} \mu \mathrm{L}^{-1}$ & $6.80 \pm 0.20$ & $7.28 \pm 0.42^{\mathrm{da}}$ & $8.56 \pm 0.35^{\mathrm{a}}$ \\
\hline NEU \% & $23.27 \pm 0.17$ & $24.46 \pm 0.32^{b}$ & $25.04 \pm 0.17^{\mathrm{e}}$ \\
\hline MON \% & $7.21 \pm 0.32$ & $7.52 \pm 0.37$ & $7.91 \pm 0.52$ \\
\hline LYM \% & $32.88 \pm 0.29$ & $33.23 \pm 0.23^{a c}$ & $33.65 \pm 0.25^{c}$ \\
\hline EOS \% & $4.43 \pm 0.03$ & $4.51 \pm 0.24$ & $4.33 \pm 0.23$ \\
\hline BAS $\%$ & $0.73 \pm 0.003$ & $0.74 \pm 0.007$ & $0.75 \pm 0.009$ \\
\hline $\mathrm{Pt} \%$ & $339.40 \pm 0.74$ & $340.84 \pm 0.55$ & $340.85 \pm 1.35^{\mathrm{b}}$ \\
\hline
\end{tabular}

Dandapat and Sinha, 2015b). Previous FTIR analysis showed Ganoderma lucidum extract contains high protein and carbohydrates with spectra transmission peaks of 1800$1400 \mathrm{~cm}^{-1}$ and $889 \mathrm{~cm}^{-1}$ respectively (Keong et al., 2012). It was previously reported that Ganoderma spp. contains biochemicals such as alkaloids, flavonoids, reducing polysaccharides, tannins, glycosides, phenolics and steroids etc. possess medicinal values in healthcare drug delivery system and medicines (Usman et al., 2012). In present study G. applanatum extract possess good numbers of biochemical (Table 1 and Fig. 2) which are associated with bioactivity and various medicinal properties and reflects the previous studies.

Mycochemicals such as phenols, flavonoids and tannin etc. possess high antioxidant activity and reduces free radicals (Dandapat et al., 2018). In this study change of pale yellow colour of mixed solution of extract and $\mathrm{AgNO}_{3}$ solution turns into dark brown as the temperature and incubation time period increase (Fig. 3), which indicates the formation of nanoparticles due to reduction of silver ions into nanoparticles by the active mycochemicals (Firdhouse et al., 2012). The UV-visible absorption spectrum of nanoparticles showed peak at $400 \mathrm{~nm}$ (Fig. 4) corresponds to the surface plasmon resonance and according to the previous studies, formation and stability of silver nanoparticles mediated by extracts from biological sources such as plants and fungi show maximum absorption 400$500 \mathrm{~nm}$ correspond to the surface plasmon resonance (SPR) for silver nanoparticles (Khan et al., 2013; Gujral, 2015). SEM of synthesized SNPs (Fig. 5) matched with previous study report of Boswellia ovalifoliolata extract mediated SNPs of spherical shaped, 30-40 nm diameter SNPs (Gurunathan et al., 2012). Result of present study correlates with previous study of $B$. ovalifoliolata extract mediated SNPs. X-ray diffraction pattern of a powder sample provides the information pertaining to phase formation, translational symmetry present and size and shape of the unit cell are obtained from peak positions in the diffraction pattern of a sample (Brady et al., 1995). Synthesized nanoparticles mediated by from Ganoderma sessiliforme extract of $45.26 \mathrm{~nm}$ has been studied by XRD and previously it has also been reported nanoparticles synthesized using Ganoderma lucidum mycelia extract of average size $6 \mathrm{~nm}$ were analysed by XRD (Kumar $e t$ al., 2017). In present study G. applanatum extract mediated SNPs (Fig. 6 and Table 2) of average $102.08 \mathrm{~nm}$ consists of the major peaks of silver nanoparticles with fcc type lattice and some additional unassigned peaks, which may be attributed to the formation of bio-organic phase acting as surfactant for the silver nanoparticles (Kumar and Rao, 2013). Dynamic light scattering (DLS) is also known as photon correlation spectroscopy (PCS) and has been widely used for analysis of nanoparticles size in liquid phase, particle shape, colloidal stability, and surface coating (Lim et al., 2013). The result of DLS analysis of nanoparticles distribution by intensity in the colloidal solution depends upon the rate of fluctuation of intensity of the laser beam by the particles of different size bean due to Brownian motion (ZNUM, 2013; Nanocomposix, 2015). Although, an intensity distribution is the fundamental size distribution generated by DLS which is further converted to a volume distribution and the volume distribution further converted to a number distribution by inbuilt software of nanozetasizer (ZNUM, 2013). The DLS size distribution by number analysis of nanoparticles represents the total number of particles of different size bins was reported in previous study (Nanocomposix, 2015; Kumar and Sinha, 2017). Zeta potential is the electrostatic charge distribution, develops in liquid layer or capping materials on surface (stern layer) of the nanoparticles and diffuse layer present outside the stern layer which gives the potential stability of the particles in colloidal system presented in Figure 11 (ZNUM, 2013; Haider and Kang, 2015). It has been reported nanoparticles dispersion with \pm 10 to $20 \mathrm{mV}$ are moderately stable (Tucker et al., 2015). Zeta potential of nanoparticles within $-25 \mathrm{mV}$ provides efficiency of the capping material to stabilize the nanoparticles in colloid solution and their evenly distribution (Bhattacharjee, 2016). Results of DLS analysis of G. applanatum extract mediated SNPs of average size 58.78 d.nm and $-13.8 \mathrm{mV}$ correlates with the stability and highly distribution of SNPs in colloidal solution (Fig. 7 to 11 and Table 3). FTIR analysis provides confirmation of presence of biomolecules by analysis of functional groups and provides the confirmation of capping tendency of therapeutic molecules 
of biological extracts present on the surface of synthesized nanoparticles (Khan et al., 2013). Synthesized gold nanoparticles (AuNPs) by extract of G. lucidum showed strong bands of FTIR spectra at 602,1096, 1201, 1388, and $1636 \mathrm{~cm}^{-1}$ correspond to the amide polypeptides or proteins which served as capping agents in AuNPs and make them stable in colloidal solution (Gurunathan et al., 2014). In present study FTIR transmission spectra (Fig. 12) provided confirmation of capping biochemical present in $G$. applanatum extract and our results also correlates the previous studies.

Previous many studies reported that, metal nanoparticles especially silver nanoparticles are potentially toxic materials and has been used today in numerous consumer products including drug development (Imani et al., 2015). Acute oral toxicity study is necessary to determine the safer dose range to manage the clinical signs and symptoms of the drugs (Saleem et al., 2017) and the toxic outcomes of drugs such as decrease body weight, clinical signs and symptoms which are principal observations among various toxicity indicators (Ogbonnia et al., 2010). In this study non-significant increase in BW and OW was observed except testicular weight in rats treated with $200 \mathrm{mg} / \mathrm{kg}, 400 \mathrm{mg} / \mathrm{kg}$ and $2000 \mathrm{mg} / \mathrm{kg}$ doses of G. applanatum extract mediated SNPs (Table 5 and 7). Various behavioural changes due to toxicity were not observed in rats treated with different dosed of SNPs (Table 4 and 6).

In modern medical practice, toxicity studies are essential for safety of extracts or drugs used in clinical medicine because of interaction of the compound possess toxicity or its metabolite bring significant changes in haematological parameters, rapid or slow changes in structure and function of the affected tissues (Arika et al., 2016). Therefore, assessments of haematological indices provide adverse effects of foreign compounds on the blood constituents to evaluate toxicity of compounds. In this study it was observed that, $G$. applanatum extract mediated SNPs nonsignificantly $(\mathrm{p}<0.05)$ elevated in $\mathrm{RBC}, \mathrm{Hb}, \mathrm{MCHC}, \mathrm{PCV}$ and MCV indices and significantly $(\mathrm{p}<0.05)$ elevated WBC, NUT, LYM and Pt indices (Table 8). The results revealed increase $\mathrm{Hb}, \mathrm{MCH}$ and $\mathrm{MCHC}$ due to increase in $\mathrm{RBC}$ count which is associated with non-adverse and slow boost effect of haematopoietic system body (Ambali et al., 2010) and it has been reported that non-significant increase in PCV and MCV does not affect the incorporation of haemoglobin into red blood cells nor the morphology and osmotic fragility of red blood cells (Kuatsienu et al., 2017). Mushrooms have been known to possess immunstimulatory properties and increase the WBC count (Mizuno, 1999). Significant elevation of the total WBC, NUT and LYM showed an improvement in the immune system of SNPs treated animals in the toxicity study (Adedapo et al., 2004). Lymphocytes are primarily responsible for humoral antibody formation (Schalm $e t$ al., 1975) and Neutrophils are known to express receptors that specifically recognize microorganisms and efficiently ingest and destroy these pathogens (Ishikawa and Miyazaki, 2005). In present study $G$. applanatum modulated the immune response of rats and showed significant surge of WBC, NUT and LYM count of rats.

\section{Conclusions}

Ganoderma applanatum extract effectively helps to synthesize SNps within nanoscale range and the extract contains different mycochemicals associated with therapeutic properties. SNPs synthesized using $G$. applanatum did not show adverse effects on BW, OW and haematological indices. However, the, SNPs enhance the immune system of body by significant increase in total WBC count. Thus, SNPs synthesized mediated by $G$. applanatum extract at minimum doses is nontoxic to animals. More studies on at molecular level will be required to investigate the toxicity impact of SNPs.

\section{Acknowledgements}

The authors acknowledge Department of Zoology, Ranchi University for providing the working and asset facilities. The authors also acknowledge Department of Botany for their support during the collection and identification of mushrooms.

\section{Conflict of Interest}

The authors declare that there are no conflicts of interest related to this article.

\section{References}

Adedapo AA, Abatan MO, Olorunsogo OO (2004). Toxic effects of some plants in the genus Euphorbia on hematological and biochemical parameters of rats. Veterinary Archives 74(1):53-62.

Albanese A, Tang PS, Chan WC (2012). The effect of nanoparticle size, shape, and surfacen chemistry on biological systems. Annual Review of BiomedicalEngineering 14:1-16.

Ambali FS, Onukak C, Idris BS, Yaqub SL, Aliyu MH, Kawu UM (2010). Vitamin $\mathrm{C}$ attenuates short-term hematological and biochemical alterations induced by acute chlorpyrifos exposure in Wistar rats. Journal of Medicine and Medical Sciences 1(10):465-477.

Arika WM, Nyamai DW, Musila MN, Ngugi MP, Njagi ENM (2016). Hematological markers of in vivo toxicity. Journal of Hematology and Thromboembolic Diseases 4(2):1-7.

Arya V, Thakur N, Kashyap CP (2012). Preliminary phytochemical analysis of the extracts of Psidium leaves. Journal of Pharmacognosy and Phytochemistry 1(1):1-6.

Athar M, Das AJ (2014). Therapeutic nanoparticles: state-of-the-art of nanomedicine. Advance Materials Reviews 1(1):25-37.

Bhattacharjee S (2016). DLS and zeta potential - what they are and what they are not? Journal of Control Release 10(235):337-351.

Bini M, Tondo C, Capsoni D, Mozzati MC, Albini B, Galinetto P (2018). Super paramagnetic $\mathrm{ZnFe}_{2} \mathrm{O}_{4}$ nanoparticles: the effect of $\mathrm{Ca}$ and $\mathrm{Gd}$ doping. Material Chemistry and Physics 204:72-82.

Brady JB, Newton RM, Boardman SJ (1995). New uses for powder X-ray diffraction experiments in the undergraduate curriculum. Journal of Geological Education 43(5):466-470.

Chen H, Shao L, Ming T, Sun Z, Zhao C, Yang B, Wang J (2010). 
362

Understanding the photothermal conversion efficiency of gold nanocrystals. Small 6(20):2272-2280.

DandapatS, Kumar M, Ranjan R, Sinha MP (2018). Pleurotustuber-regium (Rumph. ex Fr.) Singer a potent source of antioxidant. Balneo Research Journal9(3):228-231.

Dandapat S, Kumar M, Sinha MP (2014). Synthesis and characterization of green silver nanoparticles mediated by Aegle marmelos (L.) leaf extract. In: Subbiah L, Palanisamy S, Natesan S (Ed). Nanobio pharmaceutical technology. Elsevier. A division of ReedElsevier India Pvt Ltd, pp 31-37.

DandapatS, Sinha MP (2015b). Antioxidant and anti-inflammatory activity of Pleurotustuber-regium (Rumph. ex Fr.) Singer. Advances in Biological Research 9(3):140-145.

Dandapat S, Sinha MP, Kumar M, Jaggi Y (2015a). Hepatoprotective efficacy of medicinal mushroom Pleurotus tuber-regium. Environmental andExperimental Biology 13(3):103-108.

Firdhouse MJ, Lalitha P, Sripathi SK (2012). Novel synthesis of silver nanoparticles using leaf ethanol extract of Pisonia grandis ( $\mathrm{R} \mathrm{Br})$. Der Pharma Chemica 4(6):2320-2326.

Gibson JD, Khanal BP, Zubarev ER (2007). Paclitaxel-functionalized gold nanoparticles. Journal of American Chemical Society 129(37):1165311661.

Gujral SS (2015). UV-Visible spectral analysis of boric acid in different solvents: a case study. International Journal of Pharmaceutical Sciences and Research 6(2):830-834.

Gurunathan S, Han JW, Park J-H, Kim JH (2014). A green chemistry approach for synthesizing biocompatible gold nanoparticles. Nanoscale Research Letters 9(248):1-11.

Haider A, Kang I-K (2015). Preparation of silver nanoparticles and their industrial and biomedical applications: A comprehensive review advances in materials science and engineering. Advances in Materials Science andEngineering 165257:1-16.

Holsapple MP, Farland WH, Landry TD, Monteiro-Riviere NA, Carter JM, Walker NJ, Thomas KV (2005). Research strategies for safety evaluation of nanomaterials, part II: Toxicological and safety evaluation of nanomaterials, current challenges and data needs. Toxicological Sciences 88(1):12-17.

Imani M, Halimi M, Khara $H$ (2015). Effects of silver nanoparticles (AgNPs) on hematological parameters of rainbow trout, Oncorhynchus mykiss. Comparative Clinical Pathology 24(3):491-495.

IMUSG (2002). Instruction Manual User System Guide. IRPrestige-21 (P/N 206-72010) Shimadzu Fourier Transform Infrared Spectrophotometer. Shimazu Corporation, Analytical \& measuring instrument division, Koyoto, Japan pp 3:1-27. Retrieved January 19, 2014 form http://www.nanocenter.umd.edu/equipment/ nanoopticslab/manuals/optics-03/private/IRPrestige21\%20Users\%20 System\%20Guide.pdf.

Iravani S, Korbekandi H, Mirmohammadi SV, Zolfaghari B (2014). Synthesis of silver nanoparticles: chemical, physical and biological methods. Research in Pharmaceutical Sciences 9(6):385-406.

Ishikawa F, Miyazaki S (2005). A functional role of neutrophils in the regulation of innate and acquired immunity to bacterial infection. Pakistan Journal of Biological Sciences 8:940-948.

KeongCY, Chen X,JamalJA, WangQ, Lan J (2012). Preliminary results of determination of chemical changes on Lingzhi or Reishi medicinal mushroom, Ganoderma lucidum (W.Curt:Fr.)P. Karst. (Higher Basidiomycetes) carried by Shenzhou I spaceship with FTIR and 2D-IR correlation spectroscopy. International Journal of Medicinal Mushrooms 14(3):295-305.

Khan M, Khan M, Adil SF, Tahir MN, Tremel W, Alkhathlan HZ, AlWarthan A, Siddiqui MRH (2013). Green synthesis of silver nanoparticles mediated by Pulicaria glutinosa extract. International Journal of Nanomedicine 8(1):1507-1516.

Korbekandi H, Iravani S, Abbasi S (2012). Optimization of biological synthesis of silver nanoparticles using Lactobacillus casei subsp. casei. Journal of Chemical Technology and Biotechnology 87(7):932-937.

Kuatsienu LE, Ansah C, Adinortey MB (2017). Toxicological evaluation and protective effect of ethanolic leaf extract of Launaea taraxacifolia on gentamicin induced rat kidney injury. Asian Pacific Journal of Tropical Biomedicine 7(7):640-646.

Kuila HK, Venkatesh N, Bhowmik H, Kuila U (2018). Metallic nanoparticle: a review. Biomedical Journal of Science Research Technology 4(2):1-11.

Kumar DSRS, Senthilkumar P, Surendran L, Sudhagar B (2017). Ganodermalucidum-oriental mushroom mediated synthesis of gold nanoparticles conjugated with doxorubicin and evaluation of its anticancer potential on human breast cancer MCF-7/DOX cells. International Journal of Pharmacy and Pharmaceutical Sciences 9(9):267-274.

Kumar M, Dandapat S, Ranjan R, Kumar A, Sinha, MP (2018). Plant mediated synthesis of silver nanoparticles using Punica granatum aqueous leaf extract. Journal of Microbiology and Experimentation, 6(4):175-178.

Kumar M, Sinha MP (2017). Green nanotechnology: synthesis of silver nanoparticles using aqueous leaf extract of Swertia chirayita. Notulae Scientia Biologicae 9(3):443-448.

Kumar VSS, Rao KV (2013). X-ray peak broadening analysis and optical studies of $\mathrm{ZnO}$ nanoparticles derived by surfactant assisted combustion synthesis. Journal of Nano-and Electronic Physics 5(2):20-26.

Lim JK, Yeap SP, Che HX, Low SC (2013). Characterization of magnetic nanoparticle by dynamic light scattering. Nanoscale Research Letters 8(381):1-14.

Makarov VV, Love AJ, Sinitsyna OV, Makarova SS, Yaminsky IV, Taliansky ME, Kalinina NO (2014). Green Nanotechnologies: synthesis of metal nanoparticles using plants. Acta Naturae 6(1):35-44.

Menaga D, Mahalingam PU, Rajakumar S, Ayyasamy PM (2012). Evaluation of phytochemical characteristics and antimicrobial activity of Pleurotus florida mushroom. Asian Journal of Pharmaceutical and Clinical Research 5(4):102-106.

Mizuno T (1999). The extraction and development of antitumour-active polysaccharides from medicinal mushrooms in Japan. International Journal of Medicinal Mushrooms 1(1):9-29.

Nanocomposix (2015). Nanocomposix's guide to dynamic light scattering measurement and analysis: Guidelines for dynamic light scattering measurement and analysis. V (1.5) pp 1-8. Retrieved July 25, 2016 form https://cdn.shopify.com/s/files/1/0257/8237/files/nanoComposix_ Guidelines_for_DLS_Measurements_and_Analysis.pdf/. 
Niemela T, Miettinen O (2008). The identity of Ganoderma applanatum (Basidiomycota). Taxon 57(3): 963-966.

Nishiyama N (2007). Nanomedicine: nanocarriers shape up for long life. Nature Nanotechnology 2(4):203-204.

Njoya EM, Kamini MFG, Abia WA, Pechangou SN, Njayou FN, Tchana AN, Moundipa PF (2008). Acute and sub-chronic toxicity evaluation of the aqueous extract of Codiaeum variegatum leaves on Wistar albino rodents of both sexes. Journal of Complementary Medicine Research 7(2):108-114.

OECD (2008a). Organisation for Economic Co-operation and Development (OECD) guidelines for the testing chemicals Section-4. Test No. 425, Acute oral toxicity up and down procedure pp 1-27. $\begin{array}{llll}\text { Retrieved } & 2016 & \text { April } & 25\end{array}$ https://ntp.niehs.nih.gov/iccvam/suppdocs/feddocs/oecd/oecdtg425. pdf.

OECD (2008b). Organisation for Economic Co-operation and Development (OECD). Guidelines for the testing of chemicals. 407 adopted: 3 October 2008 pp 1-13. Retrieved April 25, 2016 from https://ntp.niehs.nih.gov/iccvam/suppdocs/feddocs/oecd/oecdtg4072008.pdf.

Ogbonnia SO, Mbaka GO, Anyika EN, Osegbo OM, Igbokwe NH (2010). Evaluation of acute toxicity in mice and subchronic toxicity of hydroethanolic extract of Chromolaena odorata (L.) King and Robinson (fam. Asteraceae) in rats. Agriculture andBiology Journal of North America 1(5):859-865.

Prasad SR, Elango K, Damayanthi D, Saranya JS (2013). Formulation and evaluation of Azathioprine loaded silver nanopartilces for the treatment of rheumatoid arthritis. Asian Journal of Biomedical and Pharmaceutical Sciences 3(23):28-32.

Saleem U, Amin S, Ahmad B, Azeem H, Anwar F, Mary S (2017) Acute oral toxicity evaluation of aqueous ethanolic extract of Saccharum munja Roxb. roots in albino mice as per OECD 425 TG. Toxicology Reports 4:580-585.
Sambale F, Wagner S, Stahl F, Khaydarov RR, Scheper T, Bahnemann D (2015). Investigations of the toxic effect of silver nanoparticles on mammalian cell lines. Journal of Nanomaterials 16(1):6.

Schalm OW, Jain NC. Carrol EJ (1975). Veterinary haematology. 3rd Edition. Lea and Fabiger Publication, Philadephia pp 807-807.

Shin SW, Song IH, Um SH (2005). Role of physicochemical properties in nanoparticle toxicity. Nanomaterials (Basel) 5(3):1351-1365.

Sperling RA, Parak WJ (2010). Surface modification, functionalization and bioconjugation of colloidal inorganic nanoparticles. Philosophical Transaction of the Royal Society a Mathematical Physical and EngineeringSciences 368:1333-1383.

Tucker IM, Corbett JCW, Fatkin J, Mcneil-Watson F (2015). Laser doppler electrophoresis applied to colloids and surfaces. Current Opinion in Colloid \& Interface Science 20(4):215-226.

Usman SB, Kyari SU, Abdulrahman FI, Ogbe AO, Ahmad GY, Ibrahim UI, Sakuma AM (2012). Proximate composition, phytochemical and elemental analysis of some organic solvent extract of the wild mushroom Ganodermalucidum. Journal of Natural Sciences Research 2(4):2435.

Vilar G, Tulla-Puche J, Albericio F (2012). Polymers and drug delivery systems. Current DrugDelivery 9(4):01-28.

Wasser SP (2011). Current findings, future trends, and unsolved problems in studies of medicinal mushrooms. Applied Microbiology and Biotechnology 89(5):1323-1332.

ZhangL, Gu FX, Chan JM, Wang AZ, Langer RS, Farokhzad OC (2008). Nanoparticles in Medicine: therapeutic applications and developments. Clinical Pharmacology and Therapeutics 83(5):761-769.

ZNUM (Zetasizer Nano User manual). (2013). Zetasizernano series user manual, Malvern. MAN0485 (1.1). Retrived June 13, 2016 from https://www.malvernpanalytical.com/en/learn/knowledge-center/user manuals/MAN0485EN.html.

Zoroddu MA, Medici S, Ledda A, Nurchi VM, Lachowicz JI, Peana M (2014). Toxicity of nanoparticles. Current Medicinal Chemistry 21(33):3837-3853. 